\title{
Seasonal Dynamics and Defoliation Impact on Herbage Yield in Aspen Boreal Habitats of Alberta
}

\author{
Noble T. Donkor ${ }^{1}$, Moses M. Okello ${ }^{1}$, Robert J. Hudson ${ }^{1,3}$ And Edward W. Bork $^{2}$ \\ ${ }^{1}$ Department of Renewable Resources, University of Alberta, Edmonton, Alberta T6G 2H1 Canada \\ ${ }^{2}$ Department of Agricultural, Food and Nutritional Science, University of Alberta, Edmonton, Alberta T6G 2P5 Canada \\ ${ }^{3}$ Corresponding Author: E-mail: robert.hudson@ualberta.ca
}

Donkor, Noble T., Moses M. Okello, Robert J. Hudson, and Edward W. Bork. 2003. Seasonal dynamics and defoliation impact on herbage yield in aspen boreal habitats of Alberta. Canadian Field-Naturalist 117 (2): 196-202.

Within the aspen boreal ecosystems, little information exists on the seasonal dynamics of available herbage and the effects of varying defoliation regimes on accumulated herbage growth and associated opportunities for animal production. We examined seasonal changes in herbage phytomass in conjunction with defoliation treatments in Bromus inermis-Poa pratensis grasslands in central Alberta. Changes in herbage pools were examined by sampling at five monthly intervals from April to September 1997 and 1998, inclusive. Vegetation was also subjected to a factorial experiment with an initial defoliation in late-May, June or July, at heights of $2.5,7.5$, or $15 \mathrm{~cm}$, and repeated at 3-, 6- or 9-week intervals until the end of September. Green herbage, standing dead and fallen litter increased from spring to summer and decreased from summer to fall. Average growing conditions resulted in a peak phytomass of $350 \mathrm{~g} \mathrm{~m}^{-2}$, and varied by year. Weathering losses of green herbage, standing dead and fallen litter over winter were $34 \%, 52 \%$ and $51 \%$, respectively. Dry matter losses of total herbage (all three pools) over winter were $58 \%$ of 1997 summer green phytomass. Initial timing, height, and frequency of clipping all affected accumulated herbage yield $(\mathrm{P}<0.001)$. The greatest accumulated herbage yield was from clipping initiated in May. Light clipping resulted in less phytomass accumulation relative to moderate and heavy clipping. Clipping frequencies of six and nine weeks resulted in similar phytomass removal, but were greater than herbage removal associated with three weeks frequency. The interaction between clipping date and frequency of clipping demonstrates the importance of temporal rest and sensitivity of forage plants to defoliation, and lends support to the use of rotational grazing systems.

Key Words: herbage production, bromegrass, Bromus inermis, bluegrass, Poa pratensis, defoliation.

The Aspen Parkland and Low Boreal Mixedwood ecoregions form a gradual transitional zone in central Alberta between southern prairie and northern boreal forests (Rowe 1972; Strong 1992). Landscapes within the region largely consist of a patchwork mosaic of Trembling Aspen (Populus tremuloides) and Balsam Poplar (Populus balsamifera) forests alternating with grasslands (McCartney 1993; Bork et al. 1997). These areas contain forage resources suited to supporting beef enterprises, diversified livestock and free-ranging native ungulates (Telfer and Scotter 1975; Baron and Knowles 1984). Over the last century, this area has been increasingly influenced by European settlement and agricultural expansion resulting in significant alterations to the physiognomy of many forests and introduction of many non-native forage species such as Smooth Bromegrass (Bromus inermis) and Kentucky Bluegrass (Poa pratensis). Despite the abundance of these introduced perennial grass species, little information is available on the seasonal dynamics of available herbage and the influence of defoliation on aboveground phytomass production.

Plant-herbivore dynamics on rangelands depend on pasture productivity, changes in phytomass with time, and the vegetation's responses to defoliation (Caughley 1976; 1982; Noy-Meir 1975). Defoliation may influence the dynamic interaction between plant growth rates and phytomass, as well as change the proportions of green herbage, standing dead and fallen litter pools.
There is no definitive description or terminology for live and dead vegetation material in range ecosystems. Range ecologists have used different terms for vegetation components; e.g., above- and below ground phytomass, dead-shoot phytomass, recent dead, old-dead, mulch, litter, standing litter, ground litter, and standing dead (Odum 1960; Golley 1965; Tomanek 1969; Coupland 1979; Heitschmidt et al. 1982). For this study, green herbage refers to green photosynthesizing material of growing plants; standing dead refers to cured or dried plant material still attached to the standing plant; and fallen litter consists of detached undecayed plant residuum lying on the soil surface (Dyksterhuis and Schmutz 1947).

The timing, intensity, and frequency of defoliation interact in complex ways on production processes and herbage yield in rangeland ecosystems (McNaughton 1983; Oesterheld and McNaughton 1988; Heady and Child 1994; Zhang and Romo 1994). There are unique and important plant-animal interactions within grazed grasslands of the aspen boreal ecosystems. In particular, most of the tame pastures of Bromegrass-Bluegrass (Bromus inermis-Poa pratensis) are preferred by many free-ranging native ungulates and diversified ungulate livestock, such as Wapiti (Cervus elaphus) (Looman 1976; McCartney 1993). However, little information exists on the seasonal dynamics of available forage and the effects of alternative defoliation regimes on herbage growth which is needed to formulate improved 
management decisions related to grazing and animal production. Therefore, in this study, we used an experimental design to investigate: (1) seasonal changes in the live and dead phytomass components of a Bromus inermis-Poa pratensis community; and (2) the effects of initial timing, height and frequency of clipping on accumulated herbage removal. The study reported herein was conducted to test the following hypotheses: (1) Amounts of herbage available for grazing change seasonally; and (2) Initial timing, height and frequency of clipping would affect accumulated herbage removal.

\section{Materials and Methods}

Study Site

Field research was conducted at the University of Alberta Ministik Wildlife Research Station (53 $18^{\prime} \mathrm{N}$, $\left.114^{\circ} 35^{\prime} \mathrm{W}\right)$, located $48 \mathrm{~km}$ southeast of Edmonton, Alberta, on the Cooking Lake glacial moraine. Vegetation is classified as boreal aspen forest (Rowe 1972; Strong 1992), although homesteading in the early 1900s created characteristics more similar to those of the Aspen Parkland. Major vegetation types include Balsam Poplar (Populus balsamifera) and Trembling Aspen (P. tremuloides) forests, Bromus inermis-Poa pratensis grasslands and Threadleaf Sedge (Carex filifolia) wetlands. Seeded in the early 1950s, the grasslands are dominated by Smooth Brome (Bromus inermis) and Kentucky Bluegrass (Poa pratensis). Smooth Brome is a tall, leafy, rhizomatous, cool-season perennial that is long-lived and grows rapidly (Hardy Associates, Ltd. 1989). Kentucky Bluegrass is a shortstatured, long-lived, cool-season perennial that spreads via extensive rhizomes. Dicotyledonous plants include White Clover (Trifolium repens) and Dandelion (Taraxacum officinale). Grasses typically initiate growth in late-April or early May following snow melt, with swards dominated by vegetative graminoids in midMay. Grasses head in June with seed-ripe by midAugust. The dominant dicot, Dandelion, emerges in early-May, becomes the most visible dicot in earlyJune and persists to autumn. Following Dandelion, clovers reach their peak phytomass in July, and survive until the end of the frost-free period. Grasses senesce in late-September and October. The pastures used in this study were grazed by Rocky Mountain Wapiti (Cervus elaphus) at a stocking rate of approximately 2.0 AUM [animal unit months] $\mathrm{ha}^{-1}$ in the years prior to the study.

Average annual precipitation of the area varies from 400 to $450 \mathrm{~mm}$ with $334 \mathrm{~mm}$ falling during the growing season (April to September). Mean temperatures average $-17.3^{\circ} \mathrm{C}$ and $+17.4^{\circ} \mathrm{C}$ for January and July, respectively, with absolute temperatures ranging from -49 to $+32^{\circ} \mathrm{C}$ (Olson 1985).

Soils are mainly moderately well- to well-drained Luvisols. The upland Cooking Lake loam, which predominates in the region (Bowser et al. 1962), is a fairly well-drained Orthic Gray Luvisolic soil developed on glacial till of the Edmonton formation, underlying forested areas. The Uncas loam, an Orthic Dark Gray Luvisolic soil, also developed from glacial till, is found on less densely forested areas. Sandy loams are also present on the area, though in low proportions.

\section{Experimental Procedure}

A $20 \times 60-\mathrm{m}$ exclosure was established in April 1997 to protect plots from grazing. To ascertain the vegetation growth pattern for the area, thirty plots, each $40 \times 40 \mathrm{~cm}$, were permanently marked within the site. Clip samples were obtained at monthly intervals from five randomly selected plots from April to September 1997. All phytomass within each plot was harvested to ground level and litter removed to mineral soil. Sampling was subsequently repeated on the same plots on the same dates in 1998. This eliminated the potential effects of age differences between sites. All harvested material was hand sorted into components of live green plant material, dry plant material (standing dead), and fallen litter, dried at $60^{\circ} \mathrm{C}$, and weighed. Measurements were not made from October to March because snow cover and freezing temperatures limited field activities.

To describe the plant community in the study area, five 10-m line transects were marked across the exclosure at five regular intervals in 1998 . A $30 \times 30 \mathrm{~cm}$ quadrat was used to systematically sample along each transect in midsummer ( $\mathrm{n}=20$ quadrats). Within each quadrat, all plant species were identified and their percent cover estimated (Daubenmire 1959).

To establish the relationship between plant growth and herbage removed, clipping treatments with three initiation dates, three heights and three frequencies (e.g., intervals) were replicated six times in a completely randomized design over the two years (1997 and 1998). All plots were $40 \times 40 \mathrm{~cm}$ permanently marked, with a 10-cm clipped buffer maintained on all sides. Levels of the independent factors were: date of initial clipping (20 May, 22 June, and 22 July); heavy, moderate, and light intensities (clipping heights of $2.5,7.5$, and $15 \mathrm{~cm}$ from ground level); clipping frequency (three, six and nine week intervals after initial defoliation); and time (first and second years growth). Sub-plots of $20 \times 20 \mathrm{~cm}$ were clipped on each plot at ground level at the end of September in each year to determine residual (season-end) phytomass. Aboveground phytomass was calculated from the sum of plant material collected at each clipping date plus residual phytomass. Treatments were imposed on the same plots each year. All samples were oven-dried at $60^{\circ} \mathrm{C}$ and weighed. Mean percent soil water content (from five readings) of the 0 to $30 \mathrm{~cm}$ soil increment at the study site was measured biweekly using gravimetric (mass) method (ASTM 1980). Soil sampling sites were chosen randomly from the area between clip plots. 
TABLE 1 . Monthly precipitation, soil water and average temperatures for Ministik Wildlife Research Station, Alberta, during the growing seasons of 1997 and 1998.

\begin{tabular}{|c|c|c|c|c|c|c|c|c|c|c|}
\hline \multirow[b]{2}{*}{ Year } & \multicolumn{7}{|c|}{ Precipitation (mm) } & \multicolumn{3}{|c|}{ Air Temperature $\left({ }^{\circ} \mathrm{C}\right)$} \\
\hline & April & May & June & July & Aug. & Sept. & Total & Max. & Min. & Daily Average \\
\hline 1997 & 38 & 69 & 149 & 28 & 52 & 84 & 420 & 19 & 7 & 13 \\
\hline 1998 & 34 & 38 & 111 & 89 & 21 & 50 & 343 & 21 & 9 & 15 \\
\hline 1961-1990 & 10 & 40 & 77 & 89 & 78 & 40 & 334 & 18.6 & 7.4 & 13 \\
\hline \multicolumn{11}{|c|}{ Soil water $(\mathrm{g} / 100 \mathrm{~g})$} \\
\hline 1997 & 15 & 19 & 28 & 22 & 17 & 16 & & & & \\
\hline 1998 & 13 & 16 & 22 & 19 & 12 & 13 & & & & \\
\hline
\end{tabular}

Note: Max = average maximum daily temperature, Min = average minimum daily temperature, Daily = average daily temperature.

\section{Statistical Analyses}

Comparisons of spring, summer and fall phytomass of green herbage, standing dead and fallen litter herbage components were made. The effects of date of initial clipping, clipping height, clipping frequency and year were analyzed with a factorial analysis of variance using PROC GLM of SAS (SAS Institute, Inc. 1989). Preliminary tests prior to the ANOVA indicated no deviation from normality. Post-hoc mean comparisons were done on all significant treatment means and their interactions using Tukey's method $(\mathrm{P} \leq 0.05)$.

\section{Results}

Weather and soil water

Total annual precipitation at the Ministik area for 1997 and 1998 was 494 and $429 \mathrm{~mm}$, compared to a long-term average of $425 \mathrm{~mm}$. Growing season precipitation (April to September) in 1997 was 26\% above the long-term average (Table 1). Growing season precipitation for 1998 was slightly above average. Average air temperatures experienced during the growing season in 1997 were normal, but exceeded the average in 1998 (Table 1). Soil water content varied during the entire growing season for both years. Soil water content in the top $30 \mathrm{~cm}$ of soil increased from approximately $14 \%$ of soil weight in April to a peak of $26 \%$ in June (Table 1). Overall, weather conditions at Ministik during the growing season of 1997 were more favorable for herbage production than in 1998.

\section{Plant Composition and Seasonal Changes of Herbage Phytomass}

Plant species composition data showed a community dominated by Kentucky Bluegrass and Smooth Brome (Table 2). The three phytomass pools of green herbage, standing dead and fallen litter generally increased from spring to summer and subsequently decreased from summer to fall (Table 3). In 1997, green herbage increased by $107 \%$ from spring to summer and decreased by $39 \%$ from summer to fall. The same trend was observed in 1998 with a $105 \%$ increase and $26 \%$ decrease, respectively. Standing dead and litter followed the same trends, peaking in midsummer during both
TABLE 2. Composition (canopy cover) of major species in the Bromus inermis-Poa pratensis community at Ministik Wildlife Research Station, Alberta.

\begin{tabular}{lc}
\hline \hline Species & Composition (\%) \\
\hline Grasses and Sedges & \\
Bromus inermis & 41.3 \\
Phleum pratense & 5.8 \\
Poa pratensis & 22.1 \\
Carex filifolia & 4.8 \\
Other grasses & 2.4 \\
Forbs & \\
Achillea millefolium & 1.5 \\
Aster sagittifolius & 4.9 \\
Cirsium arvense & 1.9 \\
Lathyrus sativus & 2.2 \\
Taraxacum officinale & 8.8 \\
Trifolium repense & 3.1 \\
Other forbs & 1.2 \\
\hline \hline
\end{tabular}

years, although summer and fall pools of standing dead and litter were generally did not differ significantly from one another. Seasonal accumulation of herbage phytomass was generally greater in 1997 than 1998,

TABLE 3. Seasonal changes of herbage phytomass $\left(\mathrm{g} \mathrm{m}^{-2}\right)$ components on the Bromus inermis-Poa pratensis community at Ministik Wildlife Research Station, Alberta, in 1997 and $1998(\mathrm{n}=5)$.

\begin{tabular}{lrcc}
\hline \hline $\begin{array}{c}\text { Sampling } \\
\text { period } \\
\text { interval }\end{array}$ & $\begin{array}{c}\text { Green } \\
\text { herbage }\end{array}$ & $\begin{array}{c}\text { Standing } \\
\text { dead }\end{array}$ & $\begin{array}{c}\text { Fallen } \\
\text { litter }\end{array}$ \\
\hline $\mathbf{1 9 9 7}$ & & & \\
Spring (15 April-3 June) & $96 \mathrm{~b}^{1}$ & $77 \mathrm{c}$ & $22 \mathrm{~b}$ \\
Summer (4 June-31 July) & $208 \mathrm{a}$ & $135 \mathrm{a}$ & $44 \mathrm{a}$ \\
Fall (1 August-30 September) & $127 \mathrm{~b}$ & $113 \mathrm{~b}$ & $35 \mathrm{a}$ \\
SEM & 11 & 8 & 6 \\
$\mathbf{1 9 9 8}$ & & & \\
Spring (15 April-3 June) & $84 \mathrm{c}$ & $54 \mathrm{~b}$ & $17 \mathrm{~b}$ \\
Summer (4 June-31 July) & $178 \mathrm{a}$ & $90 \mathrm{a}$ & $45 \mathrm{a}$ \\
Fall (1 August-30 September) & $121 \mathrm{~b}$ & $74 \mathrm{a}$ & $38 \mathrm{a}$ \\
SEM & 13 & 9 & 7 \\
\hline \hline
\end{tabular}

${ }^{1}$ Within columns in a given year, means with different letters are significantly different $(\mathrm{P} \leq 0.05)$. 
likely due to the higher precipitation in 1997 . Weathering losses of green herbage, standing dead and fallen litter over winter (i.e., between fall 1997 and spring 1998) expressed as a proportion of the fall 1997 estimate were 34,52 and $51 \%$, respectively (Table 3 ). Dry matter losses of total herbage (all 3 pools) over winter were $58 \%$ of 1997 summer green phytomass.

\section{Defoliation Effects on Aboveground Productivity}

Clipping date, height and frequency all had significant effects on accumulated aboveground herbage removal between years (Table 4) and within years (data not shown). The effect of year on aboveground forage removal was independent of clipping height and frequency. Clipping date affected forage yield the most, with yield values differing significantly among all three dates investigated but peaking with May clipping (Table 5). Herbage yield following July clipping was less than half that of May. Heavy and moderate clipping intensities increased herbage removal relative to the light intensity clipping (Table 5). Raising the clipping height from 7.5 to $15 \mathrm{~cm}$ reduced herbage yield by $27 \%$. The greatest accumulated herbage yield was found with longer regrowth periods (e.g., six or nine weeks rest) (Table 5). The significant interaction between clipping date and clipping frequency (Table 4) was attributed to the increased positive effect of longer recovery times following May clipping, as well as a contrasting reduction in forage yield with longer recovery times following later initial dates of defoliation.

\section{Discussion}

Seasonal herbage production on pastures is influenced by plant community type, local growing conditions, and disturbance regime. Areas with a history of grazing are generally characterized by reduced litter (Willms et al. 1986), decreased annual production, increased losses of herbage over winter, and delayed spring growth (Willms et al. 1996). The maximum seasonal phytomass of each herbage component documented in summer coincided with wet soil conditions. In this study, there were over-winter losses of total herbage, standing dead and fallen litter. These losses are of economic importance in this area because grazing animals such as Wapiti forage through snow during winter months, and hence it is necessary to maintain a high proportion of herbage on winter ranges to ensure adequate grazing opportunities. Low spring yield in the Bromus inermis-Poa pratensis community was likely due to dry soil conditions or slow growth of plants. High herbage yield in summer was dependent on precipitation during the growing season. Shallow-rooted, rhizomatous species (like those dominant in this community) are most productive with frequent showers since moisture conservation tends to be inefficient with reduced litter (Willms et al. 1996). Clipping or grazing can also change the distribution of roots in the soil by reducing the rooting depth and packing more roots in the soil surface (Willms 1991; Smoliak et al.
TABLE 4. Analysis of Variance (F-values) of total accumulated dry matter yield from defoliation treatments at Ministik Wildlife Research Station in Alberta, 1997 and 1998.

\begin{tabular}{lcc}
\hline \hline Source of Variation & df & Yield $\left(\mathrm{g} \mathrm{m}^{-2}\right)$ \\
\hline Year (Y) & 1 & $4.50 *$ \\
Defoliation Date (D) & 2 & $65.22 * *$ \\
Defoliation Height (H) & 2 & $20.75 * *$ \\
Defoliation Frequency (F) & 2 & $31.63 * *$ \\
YxD & 2 & $4.41 *$ \\
YxH & 2 & 2.98 \\
YxF & 2 & 2.60 \\
DxH & 4 & $17.05 * *$ \\
HxF & 4 & 1.49 \\
YxDxH & 4 & 1.65 \\
YxDxF & 4 & 0.82 \\
YxHxF & 4 & 0.56 \\
DxHxF & 8 & 1.34 \\
YxDxHxF & 8 & 0.89 \\
\hline \hline
\end{tabular}

$* P \leq 0.05, * * P \leq 0.01$.

TABLE 5. Effects of defoliation date, height, and frequency on total accumulated dry matter yield (SD in parenthesis) of Bromus inermis-Poa pratensis pasture in Alberta.

\begin{tabular}{lcrr}
\hline \hline Treatments & df & \multicolumn{3}{c}{ Yield $\left(\mathrm{g} \mathrm{m}^{-2}\right)$} \\
\hline Defoliation Date (D) & 2 & & \\
May 20 & & 147.97 & $(12.37) \mathrm{a}$ \\
June 22 & & 95.27 & $(6.07) \mathrm{b}$ \\
July 22 & & 59.15 & $(4.07) \mathrm{c}$ \\
Defoliation Height & 2 & & \\
$2.5 \mathrm{~cm}$ & & 104.22 & $(10.61) \mathrm{a}$ \\
$7.5 \mathrm{~cm}$ & & 113.06 & $(10.04) \mathrm{a}$ \\
$15 \mathrm{~cm}$ & 2 & 84.47 & $(7.75) \mathrm{b}$ \\
Defoliation Frequency & & & \\
3 weeks & & 119.33 & $(3.11) \mathrm{b}$ \\
6 weeks & & 118.75 & $(5.54) \mathrm{a}$ \\
9 weeks & & & \\
\hline
\end{tabular}

Within treatments, means with different letters are significantly $(\mathrm{P} \leq 0.05)$ different.

1972). Herbage yield response to precipitation late in the growing season also tends to be low because many species have completed their growth cycle and the onset of cooler temperatures may impede growth.

Numerous studies have demonstrated the effects of fertilizer, legumes, and defoliation on grasslands in western Canada (Johnston et al. 1971; Smoliak et al. 1972; Ukrainetz et al. 1988; Pearen and Baron 1996; McCartney et al. 1999). Most of these studies have taken place on nutrient rich soils in the Black Chernozemic soil zone, rather than the less fertile Gray Luvisolic soils of the Boreal Mixedwood where many commercial game ranching enterprises are located (McCartney et al. 1999). By conducting studies on the latter, the effects of defoliation on pasture growth and productivity can be established for an area representative of a large region of central Alberta impor- 
tant for commercial livestock production, diversified ungulate livestock and free-ranging native ungulates.

In addition to the within-year seasonal variation of herbage yield and overwinter losses in phytomass, the influence of initial timing, height and frequency of clipping affected phytomass yield both within and between years in this boreal environment. These variable responses are attributed to differences in environmental conditions between years and the cumulative effects of defoliation in current and preceding years (Zhang and Romo 1994).

The greatest herbage harvested was associated with clipping initiated in May, and peaked with at least six weeks rest (regrowth). Increases in herbage yield should be more pronounced during the early active growth period of plants than later on when growth is constrained by seed-head production. This trend is particularly prevalent because the dominant grasses are all C3 species, which typically produce maximum growth by July (Zhang and Romo 1994). This pattern is also indicative of species well adapted to withstand herbivory (e.g., rhizomatous species). The decline in herbage yield associated with initial clipping in July may be due to lower soil moisture availability after mid-summer. In addition, higher temperatures in latesummer can depress forage production of cool-season species (Cooper 1979; DePeters and Kesler 1985; Mason and Lachance 1983). These results agree with other studies (e.g., Cooper 1956; DePeters and Kesley 1985; Dovel 1996), wherein pasture regrowth from defoliation in spring represented nearly half of the total growing season yield.

Moderate defoliation at all times appeared to increase herbage yield in this study. Similar results have been obtained in other studies (Robinson et al. 1952; Cooper 1956). Studies examining the effect of clipping height on yield of individual grass species suggest between 2.5 and $5 \mathrm{~cm}$ as an optimal clipping height (e.g., Reid 1966). Intensity of defoliation directly controls the herbage remaining for optimal regrowth (Heady and Child 1994). In a study adjacent to our research site that examined remaining herbage (stubble) in response to defoliation heights, Okello (1996) recorded season-long herbage stubble of 90,120 , and $170 \mathrm{~g} \mathrm{~m}^{-2}$ from $2.5,7.5$, and $15 \mathrm{~cm}$ defoliation heights. Remaining herbage values for these pastures at the $7.5-\mathrm{cm}$ clipping height exceeded the recommended level of $100 \mathrm{~g} \mathrm{~m}^{-2}$ for optimizing forage production in many pastures (Smethen 1990). Thus, a relatively intense defoliation height between 2.5 and $7.5 \mathrm{~cm}$ may be needed to optimize forage production on these particular pastures. We agree, however, with Dovel's (1996) assertion that factors other than forage yield, such as type of vegetation, stand vigor and animal performance must also be considered in determining the optimum defoliation intensity (e.g., height ).

Frequent clipping has often resulted in reduced yield compared to less frequent harvests (Ethredge et al. 1973; Owensby et al. 1974). In this study, the greatest yield was obtained from clipping no less than six weeks after initial defoliation. Rotational grazing is an important option for increasing pasture production in the Aspen Parkland (see McCartney 1999). It is obvious from these data that pastures should be rested for six weeks during rotational grazing if season-long yields are to be maintained.

The interaction between initial defoliation date and clipping frequency may be related to the phenology of plants within the study area. Plants tend to grow rapidly in the early part of the growing season, with defoliation causing photosynthates to be translocated to defoliated sites for tissue repair rather than growth (McNaughton 1979). Changes in below ground phytomass may also parallel aboveground phytomass, with root development requiring re-initiation (e.g., Johnston et al. 1971). This trend changes, however, as plants mature: growth rates decline and products of photosynthesis are preferentially utilized for reproduction (Harper 1977; Krebs 1985). Also, compensation in the defoliated plants along the growing cycle depends on the length of time available for recovery (Hilbert et al. 1981). Hence, it appears from these results that longer recovery times are more beneficial during early defoliation and vice versa.

Pasture response to defoliation varied with the growing cycle of major plants and corresponded with precipitation and soil moisture conditions. Williamson et al. (1989) stressed the need to understand the interactive role of soil water content and defoliation treatments as essential to understanding the relationship of grazing and herbage production. Maximum herbage production under defoliation may occur under certain hydrologic conditions, such as when water remains non-limiting despite grazing induced changes in root phytomass. Defoliation may also result in less water uptake and increased soil water availability later in the growing season, subsequently increasing productivity. In contrast, the lack of defoliation early in the growing season may result in early maturation of the herbage and less efficient use of any remaining soil moisture in mid- to late summer.

\section{Conclusions}

Maximum summer yield, rapid loss of green herbage late in the growing season, and dry matter losses in the standing dead and fallen litter pools over winter characterized the seasonal changes in herbage phytomass on this Aspen Boreal grassland. The amount of herbage harvested was affected by initial clipping date, clipping height and frequency of clipping. Pasture response to clipping varied with the growth cycle of major plants and also corresponded with the soil water conditions of the area. The interaction between clipping date and frequency demonstrates the importance of temporal rest and resource allocation for the sustained productivity of herbage plants. 
The defoliation intensities adopted in this study are consistent with field observations of livestock and wildlife grazing. However, we acknowledge that clipping is not equivalent to grazing as it excludes trampling impacts, shredding and the behavioral role of the grazing animal as an ecosystem regulator, selectively facilitating energy flow and the local cycling, redistribution and transformation of nutrients on the landscape. Hence, work is needed with actual grazing systems under field studies to further validate these findings. The value of our study is to show wildlife and other resource managers the need for controlled defoliation in pasture-based systems utilized by diversified ruminant livestock and free-ranging native ungulates to ensure efficient and sustainable use of these habitats.

\section{Acknowledgments}

We acknowledge the financial support of Alberta Agricultural Research Institute. We would like to thank Lisa Yadenuk, Paul Hansen and Dave HayDuk for competent fieldwork. The authors wish to thank Drs. Rod Heitschmidt, Anne Naeth and David Chanasyk for their helpful comments during manuscript preparation.

\section{Literature Cited}

American Society for Testing Materials. 1980. Standard method for laboratory determination of water (moisture) content of soil, rock and soil aggregate mixtures. ANSI/ ASTM D2216-8 Annual Book of ASTM standards, Part 19. Philadelphia. 276 pages.

Baron, V. S., and R. P. Knowles. 1984. Use and improvement of meadow brome as a pasture species for Western Canada. Proceedings of the $2^{\text {nd }}$ intermountain meadow symposium. Special series, number 34, Colorado State University and University of Wyoming Agricultural Experimental Stations.

Bork, E. W., R. J. Hudson, and A. W. Bailey. 1997. Populus forest characterization in Elk Island National Park relative to herbivory, prescribed fire, and topography. Canadian Journal of Botany 75: 1518-1526.

Bowser, W. E., A. A. Kjearsgaard, T. W. Peters, and R. E. Wells. 1962. Soil survey of Edmonton Sheet (83-H). Alberta Soil Survey Report (21). Canada Department of Agriculture.

Caughley, G. 1976. Plant-herbivore systems. Pages 99-113 in Theoretical ecology: principles and applications. Edited by R. M. May. W. B. Saunders, Philadelphia.

Caughley, G. 1982. Vegetation and the dynamics of modeled grazing systems. Oecologia 54: 309-312.

Cooper, C. S. 1956. The effect of time and height of cutting on the yield, crude protein content, and vegetative composition of native flood meadow in Eastern Oregon. Agronomy Journal 48: 257-258.

Cooper, C. S. 1979. Yields of irrigated grass and legume pasture mixtures in the Northern Rocky Mountain area. Agronomy Journal 71: 885-888.

Coupland, R. T. 1979. Grassland ecosystems of the world: analysis of grasslands and their uses. Cambridge University Press. Cambridge, England. IBP 18. 401 pages.

Daubenmire, R. F. 1959. Canopy coverage method of vegetation analysis. Northwest Science 33: 43-64.
DePeters, E. D., and E. M. Kesler. 1985. Yields and nutritive value of cuttings and permanent pasture harvested as dry hay forage. Journal of Dairy Science 68: 996-999.

Dovel, R. L. 1996. Cutting height effects on wetland meadow forage yield and quality. Journal of Range Management 49: 151-156.

Dyksterhuis, E. J., and L. M. Schmutz. 1947. Natural mulches or litter of grassland with kinds and amounts on a southern prairie. Ecology 28: 163-179.

Ethredge, J., E. R. Beaty, and M. L. Lawrence. 1973. Effects of clipping height, clipping frequency and rates of nitrogen on yield and energy content of coastal bermudagrass. Agronomy Journal 65: 717-719.

Golley, F. B. 1965. Structure and function of an old-field brome-sedge community. Ecological Monographs 35: 113137.

Hardy Associates, Ltd. 1989. Manual of plant species suitability for reclamation in Alberta (2nd edition), Alberta Land Conservation and Reclamation Council Report RRTAC 89-4. 436 pages.

Harper, J. L. 1977. Population biology of plants. Academic Press, New York. 892 pages.

Heady, H. F., and R. D. Child. 1994. Range ecology and management. Westview Press, Boulder, Colorado. 519 pages.

Heitschmidt, R. K., D. I. Price, R. A. Gordon, and J. R. Frasure. 1982. Short duration grazing at the Texas Experimental Ranch: Effects on aboveground net primary production and seasonal growth dynamics. Journal of Range Management 35: 367-372.

Hilbert, D. W., D. M. Swift, J. K. Detling, and M. I. Dyer. 1981. Relative growth rates and the grazing optimization hypothesis. Oecologia (Berlin) 51: 14-18.

Johnston, A., J. F. Dormaar, and S. Smoliak. 1971. Longterm grazing effects on fecue grassland soils. Journal of Range Management 24: 185-188.

Krebs, C. J. 1985. Ecology: the experimental analysis of distribution and abundance. 3rd edition. Harper and Row Publishers, New York. 892 pages.

Looman, J. 1976. Productivity of permanent bromegrass pastures in the Parklands of the Prairie Provinces. Canadian Journal of Plant Science 56: 829-835.

Mason, W., and L. Lachance. 1983. Effects of initial harvest date on dry matter yield, in vitro dry matter digestibility, and protein in timothy, tall fescue, reed canary grass, and Kentucky bluegrass. Canadian Journal of Plant Science 63: 675-685.

McCartney, D. H. 1993. History of grazing research in the Aspen Parkland. Canadian Journal of Animal Science 73: 749-763.

McCartney, D. H., J. Waddington, and L. P. Lefkovitch. 1999. Animal and plant response on renovated pastures in western Canada. Journal of Range Management 52: 19-26.

McNaughton, S. J. 1979. Grazing as an optimization process: grass-ungulate relationships in the Serengeti. American Naturalist 113: 691-703.

McNaughton, S. J. 1983. Compensatory plant growth as a response to herbivory. Oikos 40: 329-336.

Noy-Meir, I. 1975. Stability of grazing systems: an application of predator-prey graphs. Journal of Ecology 63: 459481.

Odum, E. P. 1960. Organic production and turnover in old field succession. Ecology 41: 34-49.

Oesterheld, M., and S. J. McNaughton. 1988. Intraspecific variation in the response of Themeda triandra to defolia- 
tion: the effect of time of recovery and growth rates on compensatory growth. Oecologia 77: 181-186.

Okello, M. M. 1996. Dynamics of ungulate - plant grazing systems. Ph.D. thesis, University of Alberta, Edmonton. 82 pages.

Olson, R. 1985. The climate of Edmonton. Climatological studies (37), The Climate of the Canadian Cities (2), Environment Canada, Ottawa, Canada.

Owensby, C. E., J. R. Rains, and J. D. McKendrick. 1974. Effects of one year of intensive clipping on big bluestem. Journal of Range Management 27: 341-343.

Pearen, J. R., and V. S. Baron. 1996. Productivity, and composition of smooth and meadow Bromegrass mixtures with alfalfa under frequent cutting management. Canadian Journal of Plant Science 76: 763-771.

Reid, D. 1966. Studies on cutting management of grass clover swards. 4 . The effect of close and lax cutting on the yield of herbage from swards cut at different frequencies. Journal of Agricultural Science 66: 101-106.

Robinson, R. R., V. G. Sprague, and A. G. Lueck. 1952. The effect of irrigation, nitrogen fertilization, and clipping treatments on persistence of clover and on total and seasonal distribution of yields in a Kentucky bluegrass sod. Agronomy Journal 44: 239-244.

Rowe, J. S. 1972. Forest regions of Canada. Department of Environment, Canada Forest Service Publication (1300). 172 pages.

SAS Institute, Inc. 1989. SAS/STAT user's guide: Version 6, $4^{\text {th }}$ edition. Volume 2. SAS Institute Inc. Cary, North Carolina.

Smethen, M. L. 1990. Pasture management. Pages 197-240 in Pastures, their ecology and management. Edited by R. H. M. Langer. Oxford University Press, Oxford.

Smoliak, S., J. F. Dormaa, and A. Johnston. 1972. Longterm grazing effects on Stipa-Bouteloua Prairie soils. Journal of Range Mangement 25: 246-250.
Strong, W. L. 1992. Ecoregions and ecodistricts of Alberta. Volume 1. Publication of the Alberta Forestry, Lands, and Wildlife, Edmonton, Alberta.

Telfer, E. S., and G. W. Scotter. 1975. Potential for game ranching in boreal aspen forest regions of western Canada. Journal of Range Management 28: 172-180.

Tomanek, G. W. 1969. Dynamics of mulch layer in grassland ecosystems. Pages 225-240 in The grassland ecosystem and preliminary synthesis. Edited by R. L. Dix and R. G. Beidleman. IBP Range Science Department Science Series (2).

Ukrainetz, H., C. A. Campell, R. P. Zentner, and M. Monreal. 1988. Response of bromegrass to N-fertilizer, P-fertilizer and S-fertilizer on a gray Luvisolic soil in northwestern Saskatchewan. Canadian Journal of Plant Science 68: 687-703.

Williamson, S. C., J. K. Detling, J. L. Dodd, and M. I. Dyer. 1989. Experimental evaluation of the grazing optimization hypothesis. Journal of Range Management 42: 149-152.

Willms, W. D. 1991. Cutting frequency and cutting height effects on rough fescue and Parry oatgrass yields. Journal of Range Management 39: 536-540.

Willms, W.D., S. Smoliak, and A. W. Bailey. 1986. Herbage production following litter removal on Alberta native grasslands. Journal of Range Management 39: 536-540.

Willms, W. D., B. W. Adams, and J. F. Dormaar. 1996. Seasonal changes of herbage biomass on the fescue prairie. Journal of Range Management 49: 100-104.

Zhang, J., and J. T. Romo. 1994. Defoliation of a northern wheatgrass community: Above- and belowground phytomass productivity. Journal of Range Management 47: 279284.

Received 6 March 2001

Accepted 12 November 2003 